\title{
Utilization of DR1 as true RARE in regulating the $S s m$, a novel retinoic acid-target gene in the mouse testis
}

\author{
Kyuyong Han ${ }^{1,2}$, Haengseok Song ${ }^{3}$, Irene Moon ${ }^{1}$, Robert Augustin ${ }^{1}$, Kelle Moley ${ }^{1}$, Melissa Rogers ${ }^{4}$ \\ and Hyunjung Lim ${ }^{1,2}$ \\ ${ }^{1}$ Department of Obstetrics and Gynecology, Washington University School of Medicine, 660 S Euclid Avenue, St Louis, Missouri 63110, USA \\ ${ }^{2}$ Department of Biomedical Science and Technology, Institute of Biomedical Science and Technology, Konkuk University, 1 Hwayang-dong, Kwangjin-gu, Seoul \\ 143-701, Korea \\ ${ }^{3}$ Laboratory of Reproductive Biology and Infertility, Cheil General Hospital, Women's Healthcare Center, Seoul 100-380, Korea \\ ${ }^{4}$ Department of Biochemistry and Molecular Biology, UMDNJ-New Jersey Medical School, Newark, New Jersey 07101-1709, USA \\ (Requests for offprints should be addressed to $\mathrm{H}$ Lim at second address; Email: hlim@konkuk.ac.kr) \\ (I Moon is now at Department of Molecular Pharmacology and Experimental Therapeutics, Mayo Clinic College of Medicine, Rochester, Minnesota 55905, USA) \\ (R Augustin is now at Department of Pharmacology, Institute for Human Nutrition, 14482 Potsdam-Rehbrucke, Germany)
}

\begin{abstract}
Various nuclear receptors form dimers to activate target genes via specific response elements located within promoters or enhancers. Retinoid $\mathrm{X}$ receptor (RXR) serves as a dimerization partner for many nuclear receptors including retinoic acid receptor (RAR) and peroxisome proliferatoractivated receptor (PPAR). Dimers show differential preference towards directly repeated response elements with $1-5$ nucleotide spacing, and direct repeat 1 (DR1) is a promiscuous element which recruits RAR/RXR, $\mathrm{RXR} / \mathrm{RXR}$, and $\mathrm{PPAR} / \mathrm{RXR}$ in vitro. In the present investigation, we report identification of a novel RAR/RXR target gene which is regulated by DR1s in the promoter region. This gene, namely spermatocyte-specific marker $(\mathrm{Ssm})$, recruits all the three combinations of nuclear receptors
\end{abstract}

in vitro, but in vivo regulation is observed by trans-retinoic acid-activated RAR/RXR dimer. Indeed, chromatin immunoprecipitation experiment demonstrates binding of $\operatorname{RAR} \beta$ and $\operatorname{RXR} \alpha$ in the promoter region of the $S s m$. Interestingly, expression of $S s m$ is almost exclusively observed in spermatocytes in the adult mouse testis, where RA signaling is known to regulate developmental program of male germ cells. The results show that $S s m$ is a RAR/RXR target gene uniquely using DR1 and exhibits stage-specific expression in the mouse testis with potential function in later stages of spermatogenesis. This finding exemplifies usage of DR1s as retinoic acid response element (RARE) under a specific in vivo context.

Journal of Endocrinology (2007) 192, 539-551

\section{Introduction}

Retinoids, e.g. retinoic acids (RA), utilize two subfamilies of nuclear receptors, retinoic acid receptors (RARs), and retinoid X receptors (RXRs). Three subtypes of RAR, $\alpha$, $\beta$, and $\gamma$, exist as receptors of trans- and 9-cis-RAs that must form heterodimers with RXR $\alpha, \beta$, or $\gamma$. 9-cis-RA is also a ligand for RXR (Mangelsdorf et al. 1992). RXR is a promiscuous partner for many other nuclear receptors including peroxisome proliferator-activated receptors (PPARs), vitamin D receptor (VDR), and thyroid hormone receptor (TR; Mangelsdorf \& Evans 1995). While intercommunication between nuclear receptors is conceivable from sharing of a universal partner, another point of crosstalk among nuclear receptors exists at the DNA-recognition level. Dimers show differential preference towards directly repeated response elements with 1-5 nucleotide spacing, and DR1 is a promiscuous element which recruits RAR/RXR,
$\mathrm{RXR} / \mathrm{RXR}$, and PPAR/RXR in vitro (Mangelsdorf et al. 1991, Durand et al. 1992, Mader et al. 1993, IJpenberg et al. 2004). RAR/RXR heterodimer is conventionally known to regulate genes via DR5 (Chambon 1996). Thus, availability of certain nuclear receptors and their stoichiometry as well as the nature of the DNA-binding element is a crucial factor in determining how a gene is regulated by nuclear receptors.

Mammalian spermatogenesis comprises three main processes: renewal of spermatogonial stem cells by mitosis, meiosis, and production of sperms by differentiation. Genes expressed during spermatogenesis serve a wide range of functions including maintenance of general housekeeping functions, meiosis, and cellular transformation. Thus, identification of genes explicitly expressed in the testis is a key step in understanding pathophysiological processes in this tissue (Eddy 1998, Eddy \& O’Brien 1998, Cooke \& Saunders 2002). Among several signaling mediators of spermatogenesis, vitamin A derivatives are crucial for aspects 
of spermatogenesis including spermatogonia differentiation and spermiation (Kastner et al. 1996, Cupp et al. 1999). Among RA receptors, roles for $\operatorname{RAR} \alpha$ and $\operatorname{RXR} \beta$ in testis functions have been demonstrated in gene-targeted mouse models. RXR $\beta$ mutant mice have very few spermatozoa and fail to release spermatids (Kastner et al. 1996). RAR $\alpha$ mutant male mice also exhibit testis degeneration with very few germ cells (Lufkin et al. 1993). A recent study also showed that enzymes responsible for RA synthesis and degradation are compartmentalized in the mouse testis (Vernet et al. 2006), reaffirming the importance of RA signaling pathway in spermatogonia proliferation and spermatogenesis.

We previously showed that $\operatorname{PPAR} \delta$ is a receptor for cyclooxygenase-2 (COX-2)-generated prostacyclin $\left(\mathrm{PGI}_{2}\right)$ in the mouse uterus and that it mediates the process of embryo implantation (Lim et al. 1997, 1999). So far, many genes with functional PPAR response element (PPRE), a DR1, were identified from liver and adipose tissues, most of which are specific enzymes or transporters that are involved in fatty acid metabolism (Desvergne \& Wahli 1999). In an attempt to find target genes that are directly bound and regulated by PPAR $\delta /$ RXR, we employed a yeast-based system to trap functional DR1s in the mouse genome in the presence of PPAR $\delta$ and $\mathrm{RXR} \alpha$ ligands (carbaprostacyclin (cPGI) and 9-cis-RA respectively). This method was previously used to trap functional RAR-responsive elements under RA-enriched environment (Glozak et al. 2003). During screening, we identified a putative target genomic region containing two DR1s that promiscuously interacts with RXR homodimer and $\mathrm{RAR} / \mathrm{RXR}$ heterodimer, as well as PPAR/RXR heterodimer in vitro. Further characterization under in vivo conditions revealed that this DR 1 -containing region conveys RA responsiveness via ligand-activated $R A R / R X R$ dimer, rather than PPAR $\delta$ responsiveness. Our work demonstrates that restricted DR1 usage by certain nuclear receptors is achieved by compartmentalized availability of nuclear receptors. We also report identification and initial characterization of a RA-target gene regulated by these DR1s, namely spermatocyte-specific marker gene $\left(S_{s m}\right)$. $S_{s m}$ is regulated by RA and encodes a novel protein which may be involved in later stages of spermatogenesis.

\section{Materials and Methods}

Mice

Adult CD-1 mice (Charles River laboratories, Wilmington, MA, USA) were housed in the animal care facility according to NIH and institutional guidelines for laboratory animals. CD-1 and C57/B6 strains of mice were purchased from Charles River and Taconic (Germantown, NY, USA) respectively. Male mice were used as sources of various organs for RNA preparation. For gene regulation studies, male mice received an i.p. injection of $5 \mu \mathrm{M} 9$-cis-retinoic acid (9-cRA) and/or cPGI and were killed at several time points for RNA collection. Vehicle (5\% dimethyl sulfoxide (DMSO) + 95\% PBS)-injected mice served as controls.

\section{Materials}

cPGI and rosiglitazone were purchased from Cayman Chemical (Ann Arbor, MI, USA) and trans-retinoic acid (tRA) and 9-cis-retinoic acid (9cRA) from Biomol (Plymouth Meeting, PA, USA). Wy-14 643 was kindly provided by Dr S Dey (Vanderbilt University, Nashville, TN, USA). cDNAs for PPARs were provided by Dr R Evans (Salk Insistute, La Jolla, CA, USA). Mouse cDNA for $\operatorname{RXR} \alpha$ and RARs were from Dr P Chambon (Institute de Genetique et de Biologie Moleculaire et Cellulaire, Illkirch Cedex, France). Anti-peptide polyclonal antibodies for $\operatorname{PPAR} \delta$ and $\operatorname{RXR} \alpha$ were purchased from Santa Cruz Biotechnology (Santa Cruz, CA, USA). Anti-acetyl histone H4 (Lys12) and anti-RAR $\beta$ rabbit antisera were purchased from Upstate (Lake Placid, NY, USA) and Affinity Bioreagents (Golden, CO, USA) respectively.

\section{Genomic library screening in the yeast system}

The yeast strain BJ5409 is auxotrophic for His, Trp, and Ura. Yeast expression vectors containing $\operatorname{mPPAR} \delta$ (HIS3) and $\operatorname{mRXR} \alpha(T R P 1)$ were prepared and transformed into BJ5409. Transformants were selected on SD/-His/-Trp plates and were named PR5409. Expression of mPPAR $\delta$ and $\operatorname{mRXR} \alpha$ in this strain was confirmed by western blotting. The $\mathrm{p} \Delta \mathrm{SS}$ yeast reporter vector encodes $\beta$-gal under the control of a minimal $c y c 1$ promoter. A genomic DNA library was constructed to include 1-2 kb genomic DNA upstream of cyc1 promoter (Glozak et al. 2003). Thus, induction of $\beta$-gal reporter in the presence of ligand-activated PPAR $\delta / \mathrm{RXR} \alpha$ would indicate that the genomic DNA piece contains putative DR1s and serves as an enhancer for induction of the $\beta$-gal reporter gene. The PR5409 was re-transformed with $\mathrm{p} \Delta \mathrm{SS}$ genomic library and plated in the presence of cPGI (PPAR $\delta$ ligand) and 9-cis-RA (RXR ligand). Clones surviving in the absence of uracil (indicating uptake of genomic library plasmid) and showing heightened $\beta$-gal induction are selected. Transformants are then screened in two replica plates, one with and the other without ligands. Colonies with higher $\beta$-gal induction in the presence of ligands are selected and further confirmed in a more sensitive liquid $\beta$-gal assay. To make sure that single library plasmid conferred $\beta$-gal activity in this transformant, all plasmids were isolated from the yeast clone, individually transformed into bacteria, and each re-transformed into the yeast strain PR 5409. Plate and liquid orthontrophenyl-beta-galactopyranoside (ONPG) $\beta$-gal assays are described in Ausbel et al. (1997).

\section{Plasmid construction}

Mouse genomic DNA fragments of $1-2 \mathrm{~kb}$ were cloned into the $\mathrm{p} \Delta \mathrm{SS}$ plasmid, which contains the yeast cytochrome $\mathrm{c} 1$ 
(cyc1) minimal promotor and the $\beta$-gal reporter gene (Glozak et al. 2003). Full-length cDNA encoding mouse PPAR $\delta$ and $\mathrm{RXR} \alpha$ were cloned into yeast expression vectors $\mathrm{p} 423 \mathrm{ADH}$ and p424ADH (American Type Culture Collection (ATCC), Manassas, VA, USA) respectively (Mumberg et al. 1995). The P39 genomic clone originally contains $937 \mathrm{bp}$ fragment of the mouse chromosome 18. A $308 \mathrm{bp}$ fragment containing two putative DR1s ( -1332 to -1025 , numbered from the transcription start site (TSS) of Ssm) was amplified by PCR with the following primers: $5^{\prime} \mathrm{CCG}$ CTC GAG CTT CCA GCC TGA CCT CTG AC $3^{\prime}$ (39-1) and 5'CCG CTC GAG TCG AAC TCA GAA ATC CTT GC $3^{\prime}$ (39-2), and was inserted into the XhoI site in $\mathrm{p} \Delta \mathrm{SS}$. For $\beta$-gal assays in yeast, various DNA fragments of P39 were amplified by PCR and cloned into the XhoI site of $\mathrm{p} \Delta \mathrm{SS}$. Site-directed mutants of DR1s were generated by PCR amplification with specific primers (DR1_1 mutation: 5'-CCG CTC GAG GAA AGG TCt Gtc GTC AGG C-3'; DR1_2 mutation: $5^{\prime}$-CCG CTC GAG AAC TGA CAG GGC tGt cGT C-3').

For luciferase assays, the putative promoter region of the $S s m$ was amplified and cloned in pGL3 basic reporter vector (Promega). Two constructs with or without DR1s (1.6F, -1391 to $+220 ; \Delta \mathrm{DR} 1,-1031$ to +220$)$ were cloned into Xhol sites in pGL3 basic vector by PCR.

\section{Gel shift and supershift assays}

Two oligonucleotides of 45-mer including DR1_1 and DR1_2 were designed as follows: DR1_1 (5'-GAT CGT GAG GGT CAG GGA AAG GTC AGA GGT CAG GCT

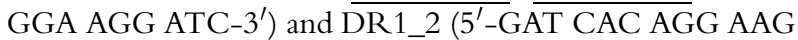
AAC TGA CAG GGC AGA GGT CAG GGT GAC AGG AGC $\left.-3^{\prime}\right)$. Each of them was annealed with opposite strand and labeled at the $3^{\prime}$ end with $\left[\gamma_{-}{ }^{32} \mathrm{P}\right] \mathrm{dCTP}$ by Klenow DNA polymerase. Nuclear receptor proteins were synthesized from mammalian expression vectors using the $\mathrm{T}_{\mathrm{N}} \mathrm{T} \mathrm{T} 7$ Quick Coupled Transcription/Translation Systems (Promega). In vitro translated proteins were mixed with $1 \mu \mathrm{g}$ poly $(\mathrm{dI}-\mathrm{dC})$ and $3 \mu \mathrm{l}$ $50 \%$ glycerol in a $30 \mu \mathrm{l}$ binding buffer $(0 \cdot 05 \mathrm{M} \mathrm{KCl}, 0.1 \mathrm{mM}$ EDTA, $12.5 \mathrm{mM} \mathrm{MgCl}_{2}, 1 \mathrm{mM}$ DTT, $25 \mathrm{mM}$ HEPES, $\mathrm{pH}$ $7 \cdot 6)$ on ice. ${ }^{32} \mathrm{P}$-Labeled double-stranded probes were then added and incubated at room temperature for $30 \mathrm{~min}$. The samples were resolved on a $5 \%$ native polyacrylamide gel in $0 \cdot 5 \times$ Tris borate buffer (TBE) and visualized by autoradiography. Unlabeled oligonucleotides were added at 10- to 100fold excess for competition assays. Supershift experiment was performed with a polyclonal antibody to the anti-PPAR $\delta$ antibody.

\section{Cell culture, transfection, and luciferase assays}

HEK293, COS7, NIH3T3 mouse fibroblast, and F9 embryonic carcinoma cell lines were obtained from ATCC. Cells were grown in Dulbecco's modified Eagle's medium (DMEM; Sigma) supplemented with 10\% FBS (Sigma), penicillin/streptomycin $(100 \mu \mathrm{g} / \mathrm{ml})$, except for F9 cells, which were grown in DMEM/F-12 supplemented with $2 \mathrm{mM}$ glutamine, $0.15 \mathrm{mM} \beta$-mercaptoethanol, $10 \%$ fetal bovine serum (FBS), and penicillin/streptomycin $(100 \mu \mathrm{g} / \mathrm{ml})$. Cells were transfected with a mixture containing FuGENE6 transfection reagent (Roche), $0.6 \mu \mathrm{g} / \mathrm{ml}$ luciferase reporter construct, $0 \cdot 2 \mu \mathrm{g} / \mathrm{ml} \beta$-galactosidase, and with or without $0.6 \mu \mathrm{g} / \mathrm{ml}$ pCDNA3-mouse $\operatorname{RXR} \alpha(\mathrm{mRXR} \alpha)$ in Opti-MEM (Gibco). All transfection reactions were normalized to a total of $2 \cdot 0 \mu \mathrm{g} / \mathrm{ml}$ plasmid DNA with pCDNA3. Ligands $(5 \mu \mathrm{M})$ or vehicle (DMSO) were added $5 \mathrm{~h}$ later. After $24 \mathrm{~h}$, cells were harvested in lysis buffer $(0 \cdot 05 \%$ Tris/MES, $\mathrm{pH} 7 \cdot 8,1 \%$ Triton X-100). Relative light units from luciferase activity were determined using LUMIstar Galaxy (BMG Labtechnologies, Durham, NC, USA) and normalized to the $\beta$-galactosidase activity. All transfection assays were repeated at least four times and statistical significance was examined by Student's $t$-test. All error bars in figures represent S.D. from the mean.

\section{$R N A$ ligase-mediated rapid amplification of $c D N A$ ends (RACE)}

Five micrograms total RNA from testis were subjected to RNA ligase-mediated RACE PCR using GeneRacer Kit (Invitrogen) according to the manufacturer's instruction. $5^{\prime}$ - and $3^{\prime}$-RACE reactions were carried out using the provided universal primer and gene-specific primers $\left(5^{\prime}\right.$ RACE: 5'-GGG CAA ACC GTT GGC AAA CCG-3', $3^{\prime}$ RACE: $5^{\prime}$-CGG CGA TCT CCT CAG GAC ATC TG-3'). Nested PCR was performed to obtain specific PCR products. RACE PCR products were cloned in pGEM T-easy vector (Promega) and sequenced to define TSS and untranslated regions (UTRs).

\section{Northern blot hybridization}

Total RNA was extracted using TRI-Reagent (Sigma), according to the manufacturer's protocol. Twenty micrograms RNA were separated by electrophoresis in formaldehydeagarose gel and transferred onto a nylon membrane (Hybond-N+; GE Healthcare Bioscience, Piscataway, NJ, USA). Hybridization with $S s m$-specific ${ }^{32}$ P-labeled randomprimed probes was carried out in MiracleHyb hybridization solution (Stratagene, La Jolla, CA, USA) at $65^{\circ} \mathrm{C}$. A $0.5 \mathrm{~kb}$ EcoRI fragment containing $S s m$ open reading frame (ORF) was used as the probe to detect transcript.

\section{Nuclei preparation}

Nuclei from adult testes were isolated according to De Lucia et al. (1996). Briefly, 6-week-old mice were anesthetized and perfused with PBS followed by $1 \%$ formaldehyde in PBS. Testes were dissected from mice and were hand-homogenized with a Teflon pestle in ice-cold $0 \cdot 25 \mathrm{M}$ sucrose solution containing $1 \mathrm{mM}$ of each $\mathrm{CaCl}_{2}, \mathrm{MgCl}_{2}$, and $\mathrm{ZnCl}_{2}$. The homogenate was centrifuged at $350 \mathrm{~g}$ for $5 \mathrm{~min}$ at $4{ }^{\circ} \mathrm{C}$. The 
pellet was hand-homogenized in $2 \cdot 2 \mathrm{M}$ sucrose solutions containing $1 \mathrm{mM} \mathrm{CaCl}_{2}, \mathrm{MgCl}_{2}$, and $\mathrm{ZnCl}_{2}$, and centrifuged at $5000 \mathrm{~g}$ for $1 \mathrm{~h}$ at $4{ }^{\circ} \mathrm{C}$. The pellet was resuspended in lysis buffer (5 mM PIPES-KOH, $85 \mathrm{mM} \mathrm{KCl,} \mathrm{0.5 \%} \mathrm{NP-40,} \mathrm{pH}$ $8 \cdot 0)$ containing protease inhibitors.

\section{Chromatin immunoprecipitation}

Isolated nuclei were sonicated for three 15-s pulses on ice and then microcentrifuged at full speed for $10 \mathrm{~min}$. At this point, a small portion of supernatant was kept as input control. Supernatant was diluted with dilution buffer $(0 \cdot 01 \%$ SDS, $1 \cdot 1 \%$ Triton X-100, $10 \mathrm{mM}$ EDTA, $16 \cdot 7 \mathrm{mM}$ Tris-Cl, $167 \mathrm{mM} \mathrm{NaCl}, \mathrm{pH} 6 \cdot 8$ ) with protease inhibitors and precleared with the addition of $80 \mu \mathrm{l}$ preblocked Protein A/G Agarose (Santa Cruz) for $4 \mathrm{~h}$ at $4{ }^{\circ} \mathrm{C}$. Preblocking of Protein $\mathrm{A} / \mathrm{G}$ agarose had been done with addition of $1 \mathrm{mg} / \mathrm{ml}$ sheared salmon sperm DNA and BSA. Precleared chromatin was divided into four separate tubes and incubated with $5 \mu \mathrm{l}$ anti-RAR $\beta$ (Affinity Bioreagents), anti-acetyl histone H4 (Lys12) (Upstate), anti-RXR $\alpha$, or rabbit IgG (Santa Cruz) overnight at $4{ }^{\circ} \mathrm{C}$ on a rotator. Immunoprecipitation, washing, and elutions were performed as described (Pattenden et al. 2002, Hofmann et al. 2004). The DNA fragments were purified with Wizard DNA purification kit (Promega). The Ssm promoter DR1-specific primers were the same as the ones used to clone $308 \mathrm{bp}$ fragment into $\mathrm{p} \Delta \mathrm{SS}$ vector.

\section{Quantitative RT-PCR}

Total RNA was purified using TRI-Reagent (SigmaAldrich) according to the manufacturer's protocol. One microgram total RNA was subjected to reverse transcription (RT) for cDNA synthesis. Quantitative RT-PCR was performed by real-time monitoring of increases in fluorescence of the SYBR Green dye as described (Wittwer et al. 1997, Morrison et al. 1998) using the ABI Prism 7000 Sequence Detection System (Applied Biosystems, Foster city, CA, USA). For comparison of transcript levels between samples, a standard curve of cycle thresholds for several serial dilutions of a cDNA sample was established and then used to calculate the relative abundance of each gene.
Values were then normalized to the relative amounts of glyceraldehyde-3-phosphate dehydrogenase (GAPDH) cDNA, which were obtained from a similar standard curve. All PCR reactions were performed in duplicate. Sequences of primers used for quantitative RT-PCR analysis are: TGC CCC CAT GTT TGT GAT G (up) and TGT GGT CAT GAG CCC TTC C (down) for the mouse GAPDH and GTG TGC TGC CTC GGA CTG A (up) and GCC GTT TGT GAC TTC CTT GG (down) for Ssm. Primers for standard RT-PCR are summarized in Table 1.

\section{In situ hybridization}

In situ hybridization was performed as described previously (Das et al. 1994). Adult mouse testis was dissected and flash frozen in Histo-Freeze (Fisher Scientific, Pittsburgh, PA, USA). Frozen sections $(12 \mu \mathrm{m})$ were mounted onto poly-Llysine coated slides (Polysciences, Inc., Warrington, PA, USA) and fixed in cold 4\% paraformaldehyde in PBS. The sections were prehybridized and hybridized at $45{ }^{\circ} \mathrm{C}$ for $4 \mathrm{~h}$ in $50 \%$ formamide hybridization buffer containing the ${ }^{35} \mathrm{~S}$-labeled antisense cRNA probes for mRARs and Ssm (specific activities $\sim 2 \times 10^{9}$ d.p.m. $/ \mathrm{ml}$ ). After hybridization and washing, the sections were incubated with RNase A $(20 \mu \mathrm{g} / \mathrm{ml})$ at $37^{\circ} \mathrm{C}$ for $20 \mathrm{~min}$. RNase A-resistant hybrids were detected by autoradiography using Kodak NTB-2 liquid emulsion (Eastman Kodak Co.). Sections hybridized with the full-length Ssm antisense probe mixed with tenfold excess cold antisense RNA served as negative controls. Slides were post-stained with hematoxylin and eosin.

\section{Immunofluorescence staining}

HEK293 cells were maintained in DMEM with glutamine, sodium pyruvate, penicillin/streptomycin, and 10\% FBS. Prior to transfection, cells were split and seeded for $24 \mathrm{~h}$ on poly-Llysine coated cover slips. Transfection of cytomegalovirus (CMV)-Myc-Ssm plasmid was carried out using the FuGene 6 reagent (Roche) according to the manufacturer's instructions. Transfected cells were analyzed for expression by immunocytochemistry $24 \mathrm{~h}$ after transfection. Cells were washed twice with PBS, fixed for $10 \mathrm{~min}$ in 3\% PFA, and quenched by three washes with $50 \mathrm{mM} \mathrm{NH}_{4} \mathrm{Cl}$ in PBS. Cells

Table 1 PCR primers used in this study

Up primer sequence

Gene
Ssm (qRT-PCR)
Ssm (RT-PCR)
PPAR $\delta$
RAR $\alpha$
RAR $\beta$
RAR $\gamma$
GAPDH

GTGTGCTGCCTCGGACTGA

AGAAAGGTAGAGGGGAGCAG

CTGGAGCTCGATGACAGTGA CTTCTGACTGTGGTGCTTG GGACCTTGAGGAACCAACAA AGGTCACCAGAAATCGATGC TGCCCCCATGTTTGTGATG

\section{Down primer sequence}

GCCGTTTGTGACTTCCTTGG
CGTCATTTGCGTCTTCTTTA
CCGTCTTCTTTAGCCACTGC
CTCTTCGGAACTGCTGCTCT
GAATGTCTGCAACAGCTGGA
CTGGCAGAGTGAGGGAAAAG
TGTGGTCATAGCCCTTCC


were permeabilized with $0 \cdot 2 \%$ saponin in PBS for $6 \mathrm{~min}$, followed by one wash in PBS/0.05\% saponin. Non-specific antiserum binding was blocked with $2 \% \mathrm{BSA} / \mathrm{PBS} / 0 \cdot 05 \%$ saponin for $30 \mathrm{~min}$. Cells were incubated with a rabbit polyclonal anti-myc antibody (Upstate Biologicals) diluted to $1 \mu \mathrm{g} / \mathrm{ml}$ in $2 \% \mathrm{BSA} / \mathrm{PBS} / 0 \cdot 05 \%$ saponin for $1 \mathrm{~h}$. Following three washes with $\mathrm{PBS} / 0 \cdot 05 \%$ saponin, a goat anti-rabbit Alexa 488 (Molecular Probes, Eugene, OR, USA) secondary antibody (1:200 in 2\% BSA/PBS/0.05\% saponin) was applied on the cells for $30 \mathrm{~min}$. Subsequently, the cells were washed with PBS/0.05\% saponin and the nuclei were stained with Topro-3 iodide (Molecular Probes) for $10 \mathrm{~min}$. After a final wash in PBS/0.05\% saponin, the coverslips were mounted using Vectashield (Vector Laboratories, Verlingame, CA, USA). Specimens were examined by confocal microscopy using a Nikon C1 confocal microscope.

\section{Result}

Screening of the mouse genomic library in a yeast system and characterization of the clone P39

Our original intention was to identify putative DR1containing genomic regions under regulation of PPAR $\delta / R X R$ using a yeast-based genomic element-trapping method. The experimental schematic is shown in Fig. 1. This genomic element-trapping method was previously used for finding cognate response elements of RAR (Glozak et al. 2003). It has been demonstrated that many aspects of nuclear receptor signaling can be faithfully reconstituted in yeast (Hall et al. 1993, Marcus et al. 1995). Screening was performed in the presence of cPGI and 9cRA, ligands for PPAR $\delta$ and RXR respectively. This was to enrich binding of transformed receptors to $\mathrm{DR} 1$ region. As mentioned above, $\mathrm{DR} 1 \mathrm{~s}$ are also targets of RXR/RXR homodimer or RAR/RXR heterodimer (Mangelsdorf et al. 1991, Durand et al. 1992, Mader et al. 1993, IJpenberg et al. 2004).

One clone, namely P39, was selected many times during screening. P39 contains an approximately $1 \mathrm{~kb}$ genomic insert and initial subcloning and $\beta$-gal assays in the presence of $\mathrm{CPGI}$ and $9 \mathrm{cRA}$ showed that the first $308 \mathrm{bp}$ fragment proximal to the cyc1 minimal promoter contains ligand-responsive element(s) (Fig. 2A). All the three members of PPAR family (as heterodimer with $\mathrm{RXR} \alpha$ ) were able to induce reporter activation in the presence of their cognate ligands in the yeast system as determined by ONPG liquid $\beta$-gal reporter assays (data not shown). Since RXR also forms homodimer, we also performed similar reporter assays using a yeast strain which only expresses mouse $\operatorname{RXR} \alpha$. Indeed, $\beta$-gal activity was detected in the presence of 9cRA alone. Thus, P39 contains genetic elements which respond to both $\operatorname{PPAR} \delta / \mathrm{RXR}$ and RXR/RXR dimers. Sequencing analysis revealed that there are two well-conserved DR1s in this fragment of P39 (Fig. 2A). In the yeast PR5409, site-directed mutagenesis or deletion of either element from P39 in p $\Delta$ SS abrogated $\beta$-gal reporter activation, showing both elements are required for the induction of $\beta$-gal reporter (Fig. 2A). To examine whether the orientation of these DR1s is crucial for ligand responsiveness, we cloned 308 bp fragment containing two DR1s of P39 in

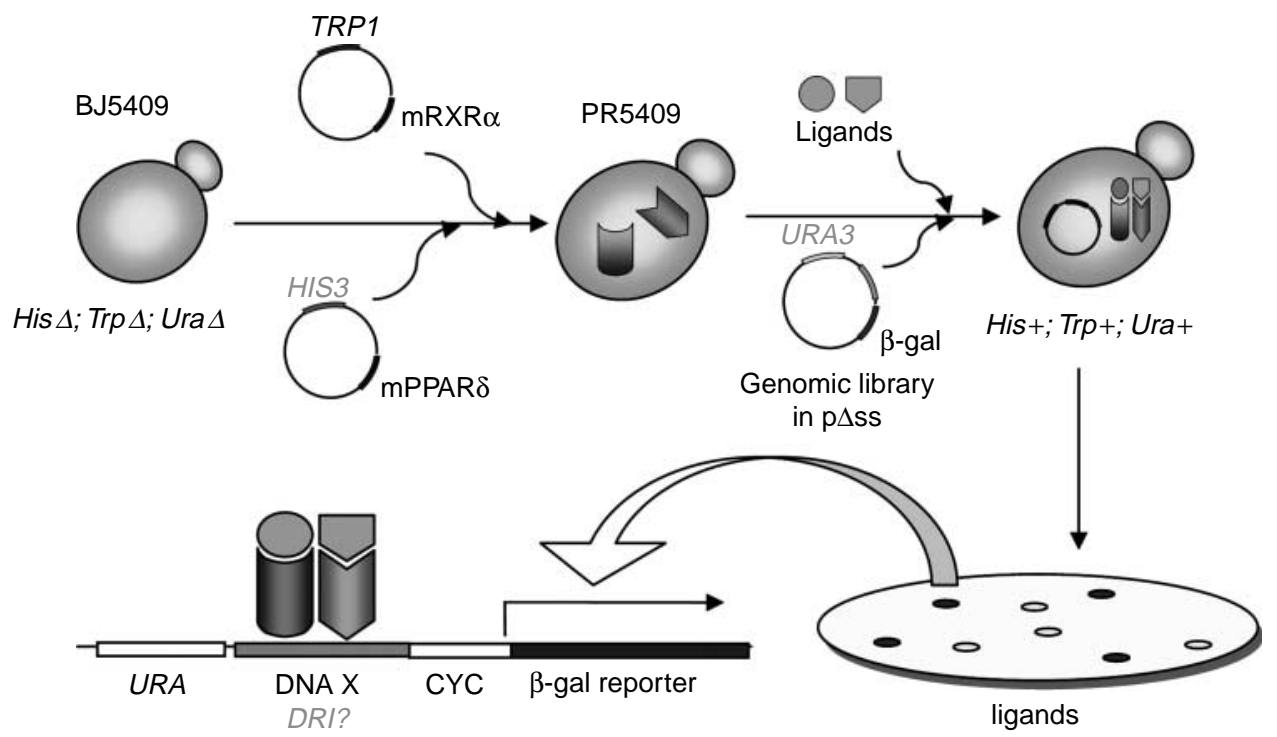

Figure 1 Trapping novel DR1s from the mouse genomic library using a yeast-based system. The yeast strain BJ5409 is an auxotroph for His, Trp, and Ura. Yeast expression vectors containing mPPAR $\delta$ and $\mathrm{mRXR} \alpha$ were prepared and transformed into the BJ5409. Transformants (PR5409) were selected on SD/-His/-Trp plates and re-transformed with $\mathrm{p} \Delta \mathrm{SS}$ genomic library. They were plated onto SD/-Ura in the presence of cPGI and 9cRA for selection. A replica plate containing no ligand was compared for selecting colonies which turn blue only in the presence of ligands. Candidate colonies were further screened by liquid ONPG $\beta$-gal assay. 
A

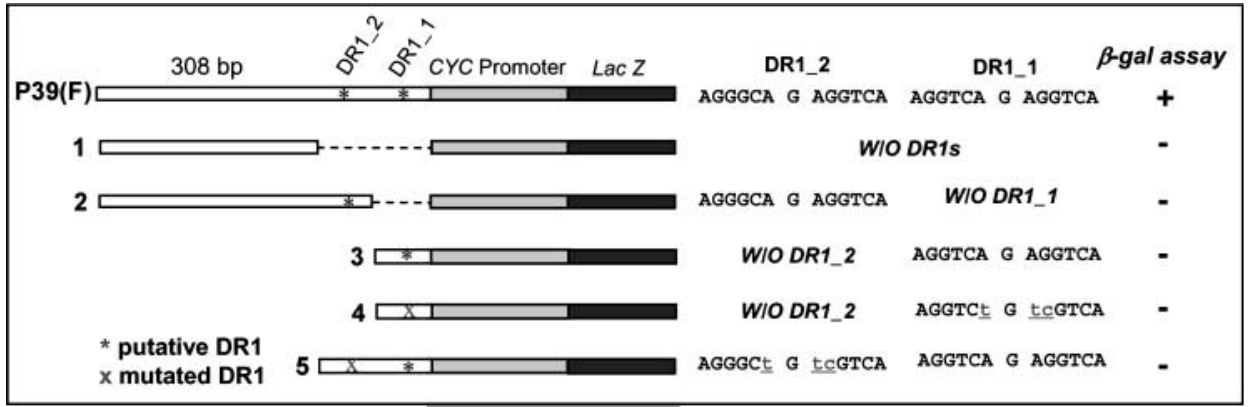

B DR1_1

DR1_2
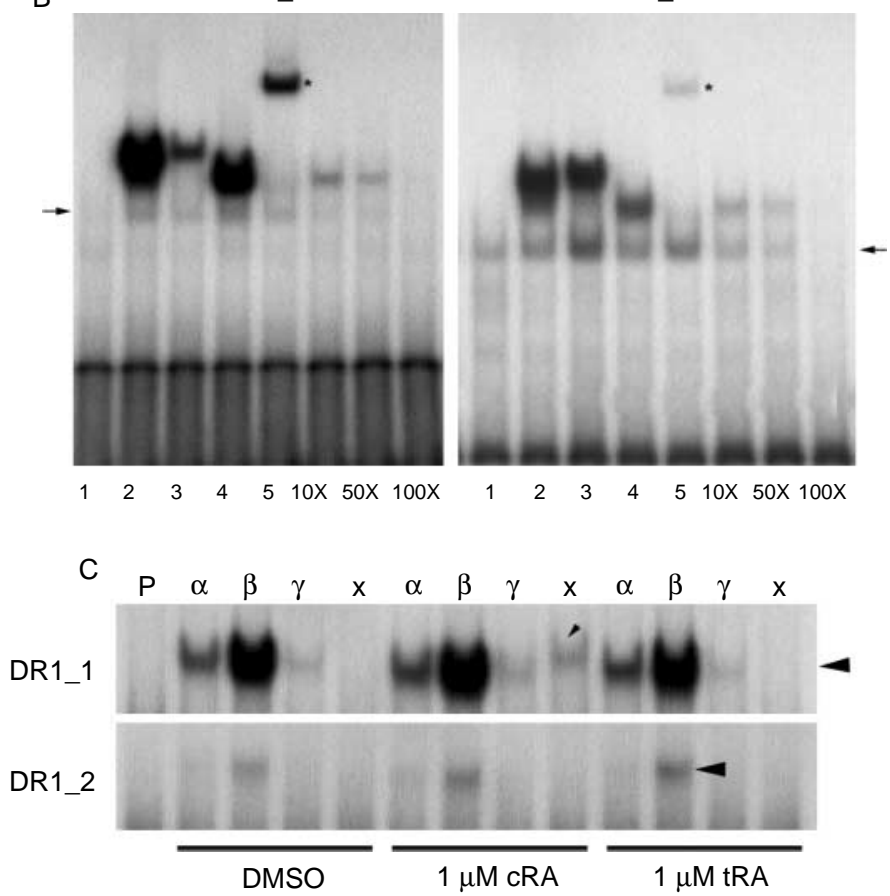

Figure 2 Functionality of putative DR1s in P39. (A) From the 937 bp clone P39, a 308 bp fragment containing two putative DR1s was subcloned into the yeast reporter vector $\mathrm{p} \Delta \mathrm{SS}$. Constructs in forward $(\mathrm{F})$ and reverse $(R)$ orientations as well as with deletions or mutations (1-5) were generated as shown. Liquid ONPG test was performed to monitor $\beta$-gal reporter activity of these constructs in the presence of ligands (CPGI and 9cRA). (B) Gel shift assay was performed with double-stranded ${ }^{32}$ P-labeled DR1_1 and DR1_2 oligonucleotides and in vitro translated receptors. Competitor DNA was added at 10- to $10 \overline{0}$-fold excess relative to the labeled DNA. 1, labeled DNA alone; 2, PPAR $\alpha$ plus RXR $\alpha$; 3, PPAR $\gamma$ plus RXR $\alpha ; 4$, PPAR $\delta$ plus $\operatorname{RXR} \alpha ; 5$, supershift by anti-PPAR $\delta$ antibody; 10-100X, competition with excess cold probe at 10-100X. *Supershifted band. Binding was not ligand dependent. Arrows indicate location of a non-specific band which also appears in the absence of any nuclear receptor. (C) DR1_1 and DR1_2 were subjected to gel shift assays with in vitro translated RAR $\alpha, \operatorname{RAR} \beta, \operatorname{RAR} \gamma$ along with RXR $\alpha$. Ligand was added as shown. P, probe only; $\alpha, \operatorname{RAR} \alpha ; \beta, \operatorname{RAR} \beta ; \gamma, \operatorname{RAR} \gamma ; x, \mathrm{RXR} \alpha$; CRA, 9-cis-retinoic acid; tRA, trans-retinoic acid. All the three RARs are capable of binding to these DR1s in the presence of $R X R \alpha$, but ligand is not required. Note the strongest binding by RAR $\beta / R X R \alpha$. RXR $\alpha$ homodimer binds to DR1_1 only in the presence of cRA. Large arrowheads indicate RAR/RXR heterodimer, and small arrowheads RXR/RXR homodimer.

forward (F, shown in Fig. 2A) and reverse (not shown) orientations into $\mathrm{p} \Delta \mathrm{SS}$ and $\beta$-gal activity was examined. The result showed that only the construct $\mathrm{F}$ was responsive in yeast $\beta$-gal assays. Either deletion or mutation of a DR1 in the construct $\mathrm{F}(1-5)$ abrogated reporter activity (Fig. 2A).
We then tested whether these putative DR1s in P39 recruit nuclear receptor dimers in gel shift assays. Three subfamilies of nuclear receptors that recognize DR1 elements were tested. As shown in Fig. 2B, all the three PPARs were capable of binding to DR1_1 and DR1_2 in the presence of $\operatorname{RXR} \alpha$, but 
ligand was not needed. When cold DR1_1 or DR1_2 was added in excess to the binding reaction of $\operatorname{PPAR} \delta / \operatorname{RXR} \alpha$, the interaction was competed off. Addition of anti-PPAR $\delta$ antibody decreased the mobility of $\operatorname{PPAR} \delta / \mathrm{RXR} \alpha$ dimer, showing the specificity of this interaction. All the three RARs in the presence of $\operatorname{RXR} \alpha$ also bound to DR1_1, and the ligand did not enhance binding affinity (Fig. 2C). RAR $\beta$ showed the strongest affinity. RXR alone (RXR homodimer, small arrowhead) was able to bind to DR1_1 only in the presence of 9cRA. As for DR1_2, only the binding of $\operatorname{RAR} \beta / \mathrm{RXR}$ heterodimer was observed. Collectively, this result suggests that DR1_1 and DR1_2 within P39 are capable of recruiting several combinations of nuclear receptors depending on availability. Thus, during initial screening in yeast, it is possible that P39 could have been activated by $9 \mathrm{cRA}$-activated $\mathrm{RXR} \alpha / \mathrm{RXR} \alpha$ homodimer, as well as $\operatorname{PPAR} \delta / \mathrm{RXR} \alpha$ heterodimer.

\section{Both DR1s belong to a promoter region}

The result that only the construct $\mathrm{F}$ was responsive to ligands in yeast prompted us to look for an ORF $3^{\prime}$ to this fragment on the mouse genome. A BLAT database search (http:// genome.ucsc.edu/cgi-bin/hgBlat) revealed that an expressed sequence tag (EST) (AK005654) is located within $\sim 1.2 \mathrm{~kb}$ vicinity of the DR1s of P39 on the mouse chromosome 18. AK005654 is originally identified from RIKEN full-length enriched library of the mouse adult testis cDNA library (Okazaki et al. 2002). In order to examine whether DR1s are functional elements within the promoter of this EST, we cloned two genomic fragments into a basic luciferase reporter vector containing no promoter ( $\mathrm{pGL3}-\mathrm{Basic}$ ). The construct $1 \cdot 6 \mathrm{~F}$ contains about $1.6 \mathrm{~kb}$ upstream of the coding region, and the construct $\Delta \mathrm{DR} 1$ was cut upstream of the DR1_1. In the transfection assays using HEK293 and F9 cells, RXR $\alpha$ was added along with 9cRA or tRA. As shown in Fig. 3, both 9cRA and tRA enhanced transcriptional activity of $1.6 \mathrm{~F}$ up to $\sim$ six- to seven-fold in F9 mouse embryonic carcinoma cells. When DR1s were deleted $(\Delta \mathrm{DR} 1)$, this response was abrogated. Addition of PPAR $\delta$ and its ligand in transfection assays did not provoke significant response of the reporter construct (data not shown). The fact that both 9cRA and tRA are responsive suggests a possibility that DR1s in the AK005654 promoter primarily convey RA responsiveness via $\mathrm{RAR} / \mathrm{RXR}$ heterodimer in RAR-enriched F9 cells. We then sought to further characterize regulation and expression of this novel gene under in vivo conditions.

\section{Gene structure of $A K 005654$}

Sequencing analysis confirmed that the ORF of AK005654 is 584 bp long with two exons and one intron. RNA ligasemediated RACE (RLM-RACE) confirmed the TSS and UTRs. Gene structure is shown in Fig. 4. The coding region encodes a small protein of 38 amino acids, but the protein does not bear homology to any known protein (GenBank accession no. DQ284430).

\section{AK005654 is expressed in the mouse testis and uterus}

We examined tissue-specific expression of AK005654 using northern blot hybridization and quantitative RT-PCR (qRTPCR). Northern blot hybridization using total RNA samples and a sequence-specific probe detected a band of $<1 \mathrm{~kb}$ transcript only in the mouse testis (Fig. 5A). A more sensitive qRT-PCR analysis showed that testis expresses AK005654 mRNA abundantly and uterus also shows detectable levels of AK005654 mRNA. No other tissues included in this survey showed expression (Fig. 5B).

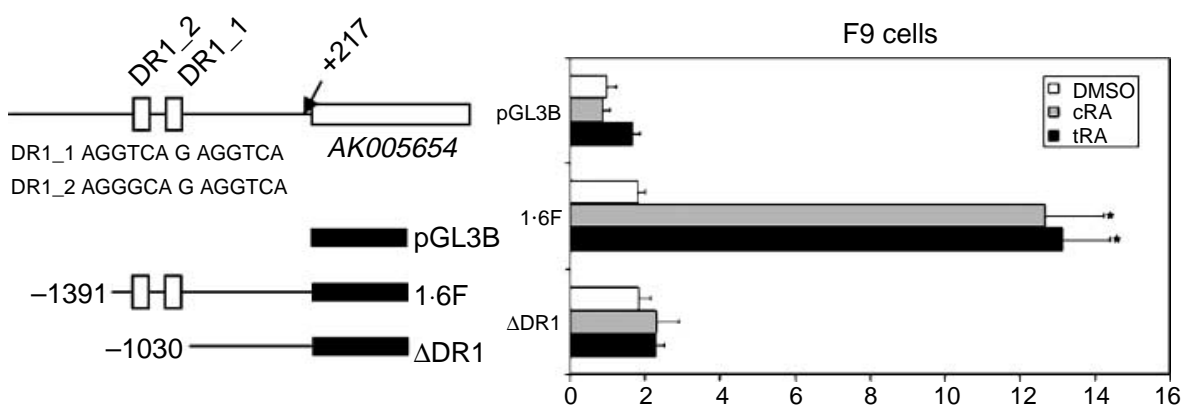

Figure 3 Functionality of DR1s and identification of the promoter region in mammalian cells. Promoter constructs containing $1.6(1 \cdot 6 \mathrm{~F})$ or $1 \cdot 2 \mathrm{~kb}(\Delta \mathrm{DR} 1)$ upstream from the beginning of the coding region were cloned into the basic luciferase vector pGL3-basic (pGL 3B). HEK293 (data not shown) or F9 cells were transfected with $\mathrm{mRXR} \alpha$ and indicated reporter construct for $5 \mathrm{~h}$. Cells were then treated with vehicle (DMSO) or indicated ligand $(5 \mu \mathrm{M})$ for $24 \mathrm{~h}$. Transcriptional response was measured by luciferase activity of reporter construct and was normalized to the internal control of $\beta$-galactosidase activity. Data are presented as fold activation relative to vehicle-treated cells in the same group and represent the mean from at least three independent transfection experiments. See Materials and Methods for details. Error bars represent S.D. and statistical significance was examined by a Student's $t$-test. ${ }^{*} P<0 \cdot 01$. 


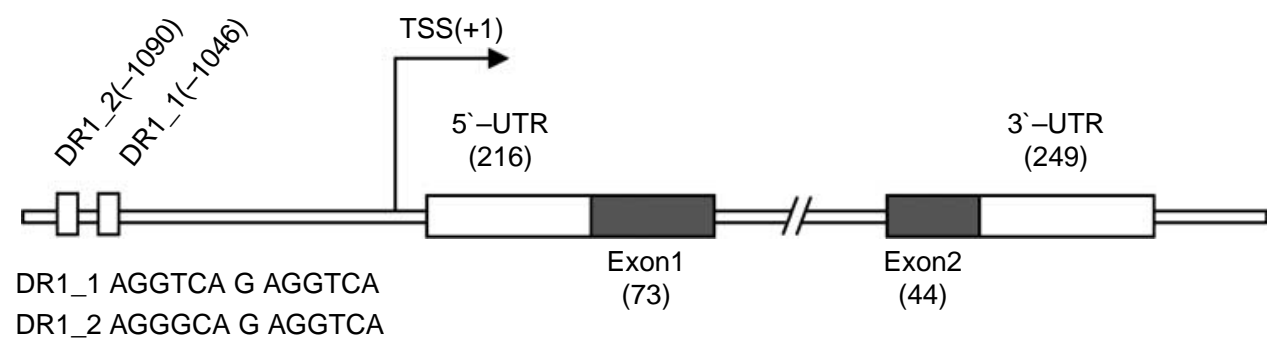

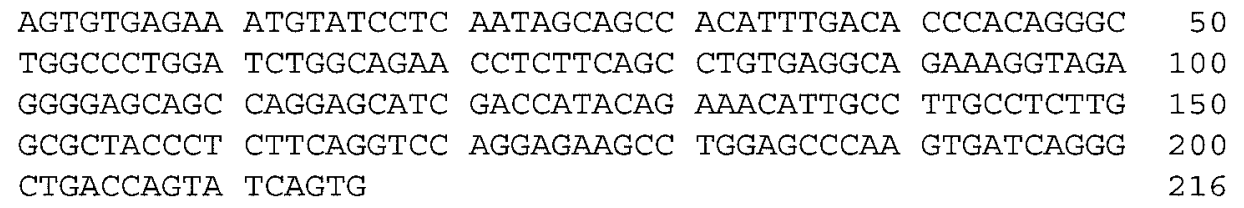

ATG GAT GCG ATC GGC GAT CTC CTC AGG ACA TCT GTC AGT GTG 258

$\begin{array}{llllllllllllll}M & \text { D } & \text { A } & \text { I } & G & \text { D } & \text { L } & \text { L } & \text { R } & \text { T } & \text { S } & \text { V } & S & \text { V }\end{array}$

CTG CCT CGG ACT GAT CCC TTT ACC AGC CTA GTG CTT CCT ACC 300

$\begin{array}{llllllllllllll}\mathrm{L} & \mathrm{P} & \mathrm{R} & \mathrm{T} & \mathrm{D} & \mathrm{P} & \mathrm{F} & \mathrm{T} & \mathrm{S} & \mathrm{L} & \mathrm{V} & \mathrm{L} & \mathrm{P} & \mathrm{T}\end{array}$

ACA GGG GAG GAA GGG AGC CCG CCT TCA AGC TGA 333

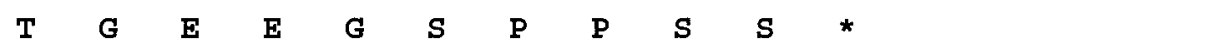

AGTGAGATCA CCTCATCCAA GGAAGTCACA AAGGGCTGAC AGTGCAGATC 383

ATCTCTGTGC ACTCTGGAAG CATCAGGAAG CCATTAAAGA AGACGCAAAT 433

GACGTCAATA CCTCAACGGT TTGCCAACGG TTTGCCCTAA ACAAGGAGTT 483

TAGAGAAATG CTACATTATT TTTAAAGGCC TGGGAATTCC AAGAGCCGTA 533

GTACAGTATT GTCAAACTGT GTGGTTTGCT TTAAACAATT GTTGCAATT 582

Figure 4 Sequence of the mouse $S s m$, a novel RA-target gene. Nucleotide sequence of $S s m$ and predicted amino acid sequence are shown. Untranslated regions of $5^{\prime}$ and $3^{\prime}$ are shown along with translated ORF. Ssm is located on the mouse chromosome 18. It encodes a small protein of 38 amino acid and has one intron and two exons (gray boxes). The 5'UTR and 3'UTR (open boxes) were confirmed by the $5^{\prime}$ and 3'-RACE respectively. GenBank accession no. DQ284430. UTR, untranslated region; TSS, transcription start site.

Since testis is the primary site of expression, we sought to determine whether RA and/or cPGI administration in vivo enhances expression of AK005654 in this tissue. We injected $5 \mu \mathrm{M} 9 \mathrm{cRA}$ intraperitoneally and killed the mice at several time points. Then qRT-PCR was performed using total RNA from testes. However, we did not observe significant increases in the level of expression in the testis of 9cRA- or cPGI-treated mice in comparison with vehicle-treated mice (data not shown). Combination of 9cRA and cPGI also did not upregulate $S s m$ expression. This may be due to high constitutive levels of AK005654 expression under constant production of RA in this tissue (Vernet et al. 2006).

\section{AK005654 exhibits cell type-specific expression in the mouse testis}

Our finding that testis is the primary tissue expressing this novel gene suggests that AK005654 is a unique marker gene of male reproductive functions. To examine cell type-specific expression of AK005654, we performed in situ hybridization using ${ }^{35}$ S-labeled antisense riboprobe of the full-length cDNA in testes of 6-week-old mice. Notably, the message was observed inside certain, but not all, seminiferous tubules, suggesting that this gene exhibits stage-specific expression in male germ cell population. Closer examination showed that AK005654 mRNA is localized in spermatocytes, but not in spermatogonia or mature sperm (Fig. 6A). We compared its expression with $\mathrm{Rbm}$, a marker gene expressed in the spermatogonia and primary spermatocytes (Lee et al. 2004). Expression pattern of AK005654 and $\mathrm{Rbm}$ were distinct (Fig. 6A). This result suggests that AK005654 is involved in a stage-specific function during spermatogenesis. Based on cell-type specificity of its expression, we named this EST as Spermatocyte-specific marker (Ssm). In the uterus, Ssm did not exhibit notable cell type-specific expression pattern (data not shown).

Our transfection assays earlier showed that both RXR and RAR bind to DR1s in the promoter region of 
A

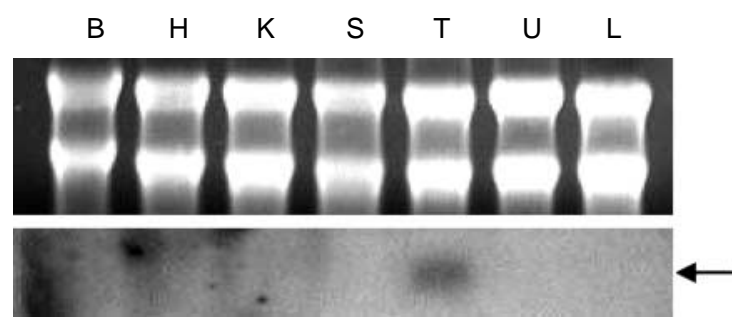

B

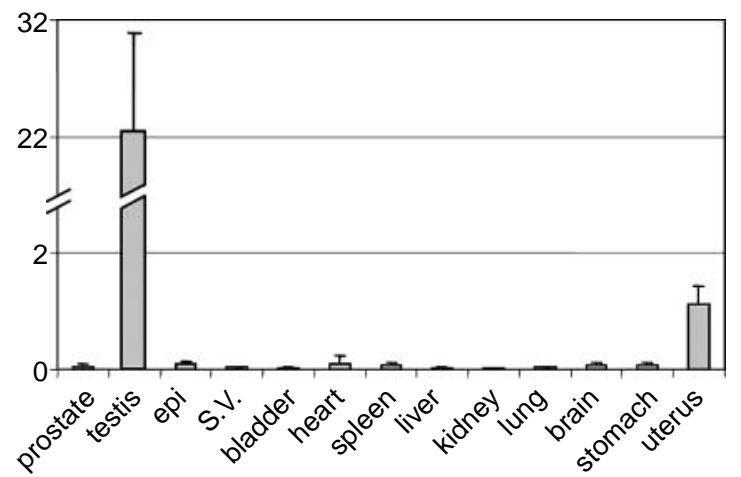

Figure 5 Expression profile of $S s m$. (A) Northern blot hybridization of $S s m$. A single band below $1 \mathrm{~kb}$ is detected only in the testis (arrow). B, brain; $\mathrm{H}$, heart; $\mathrm{K}$, kidney; $\mathrm{S}$, spleen; T, testis; $\mathrm{U}$, nonpregnant uterus; L, liver. (B) Quantitative RT-PCR was performed using total RNA samples from various tissues as indicated. $S s m$ is highly expressed in the testis and at much lower levels in the uterus. Other tissues do not express detectable levels of Ssm. S.V., seminal vesicle; epi, epididymis.

Ssm and that RA upregulates promoter activity via these elements. Furthermore, RA is an important mediator of spermatogenesis and testis function (Lufkin et al. 1993, Kastner et al. 1996). Thus, we examined which members of RA receptors exhibit similar expression pattern with $S s m$ in the mouse testis. In situ hybridization shows that $\operatorname{RAR} \alpha$ and $\operatorname{RAR} \gamma$ are expressed in all seminiferous tubules (Fig. 6B). RAR $\alpha$ was strongly expressed in all cell types of the tubules, while $\operatorname{RAR} \gamma$ exhibited weak expression in basal side of the tubules. In contrast, RAR $\beta$ was expressed only in certain tubules. Closer examination showed that RAR $\beta$ is expressed in spermatocytes, resembling the expression pattern of the $S s m$. We also examined expression of $S s m$ in mouse testis from 2- to 6-week-old mice. Since spermatocyte production starts with onset of puberty when gonadotropins are available, we expected that Ssm expression would not be observed in testis of younger mice. Indeed, standard RT-PCR analysis comparing expression of $\operatorname{RAR} \alpha, \operatorname{RAR} \beta, \operatorname{RAR} \gamma$, and PPAR $\delta$ along with $S s m$ show that $S s m$ expression is observed in testes from 4-week-old mice, and this expression is similar to $\operatorname{RAR} \beta$ (Fig. 6C). $\operatorname{RAR} \alpha, \operatorname{RAR} \gamma$, and $\operatorname{PPAR} \delta$ are expressed in all age groups. This suggests that $\operatorname{RAR} \beta$ and $S s m$ are expressed in a similar type of cells around the onset of spermatogenesis and that $\operatorname{RAR} \beta$ may sit upstream and regulate expression of this gene under in vivo conditions. Collectively, the results show that RARs are available to convey RA responsiveness for the regulation of $S s m$ in spermatocytes and that $S s m$ is a putative RA-target gene which functions during spermatogenesis.

\section{In vivo chromatin precipitation of the DR1 region by $R A R \beta$}

Our transfection analyses and in situ hybridization suggest that $S s m$ is a potential target gene of RAR signaling. Among three members of RARs, RAR $\beta$ exhibits co-expression with $S s m$ in spermatocytes (Fig. 6B) and also shows strong binding to DR1_1 and DR1_2 in vitro (Fig. 2). Thus, to test the hypothesis that $\mathrm{Ssm}$ expression in spermatocytes is directly regulated by binding of RAR/RXR heterodimer in vivo, we performed in vivo chromatin immunoprecipitation using nuclei preparation from the mouse testis. DNA-protein complexes were immunoprecipitated with antibodies to acetylated histone $\mathrm{H} 4, \mathrm{RXR} \alpha$, or RAR $\beta$. While acetylated histone $\mathrm{H} 4$ antibody was used as a positive control, rabbit IgG served as a negative control. The cross-links were reversed and the DNA that co-purified with the immunocomplexes was amplified with primers specific for the DR1 region of the $S s m$ promoter. As shown in Fig. 7A, acetylated histone 4B, $\operatorname{RXR} \alpha$, and $\operatorname{RAR} \beta$ were recruited to the $\mathrm{DR} 1$ region of the Ssm promoter under in vivo conditions. This result clearly shows that the $S s m$ is a direct target gene of the RA signaling pathway in the testis during spermatogenesis.

\section{Subcellular localization of Ssm}

The protein sequence of $S s m$ does not bear homology to any distinct family of proteins. To gain insights into the type of protein $S s m$ encodes by determining subcellular localization, we cloned a myc-tagged Ssm into a CMV-driven mammalian expression vector. This construct was transfected into HEK293 or COS7 cells and protein expression was observed by confocal microscopy. As a control, we transfected CMVMyc empty vector. As shown in Fig. 7B, staining with antimyc antibody showed that $S s m$ is widely distributed in the cytoplasm, and sometimes both in the nucleus and cytoplasm. Control vector did not give specific localization (data not shown). Ssm localization does not seem to be confined to certain subcellular organelles of cells in culture. We are further investigating cellular function(s) of $S s m$.

\section{Discussion}

The present investigation reports identification of a novel RA-target gene in the testis, namely $S s m$, using a yeast-based genomic element-trapping method (Glozak et al. 2003). This method is effective in trapping response elements of ligandactivated transcription factors, since comparison between plates with or without ligands along with auxotrophic 
A
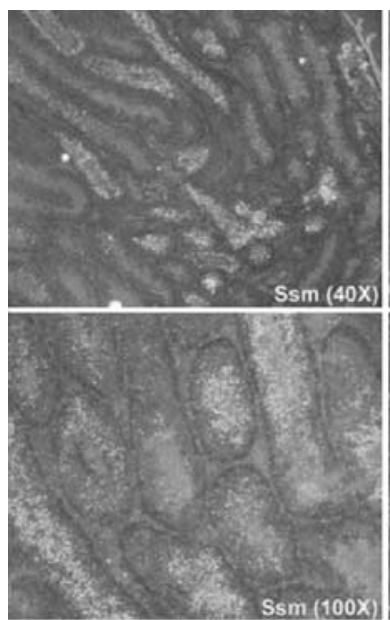
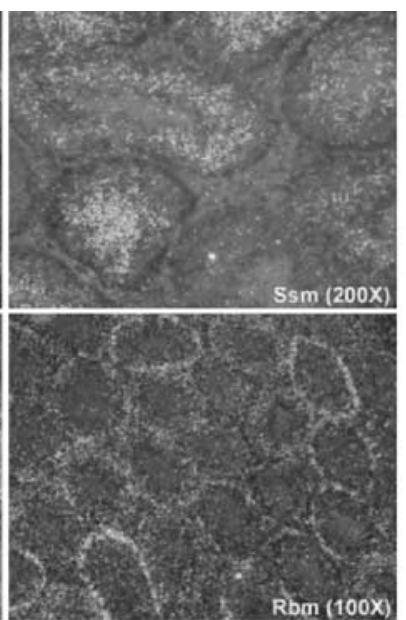

\section{B}
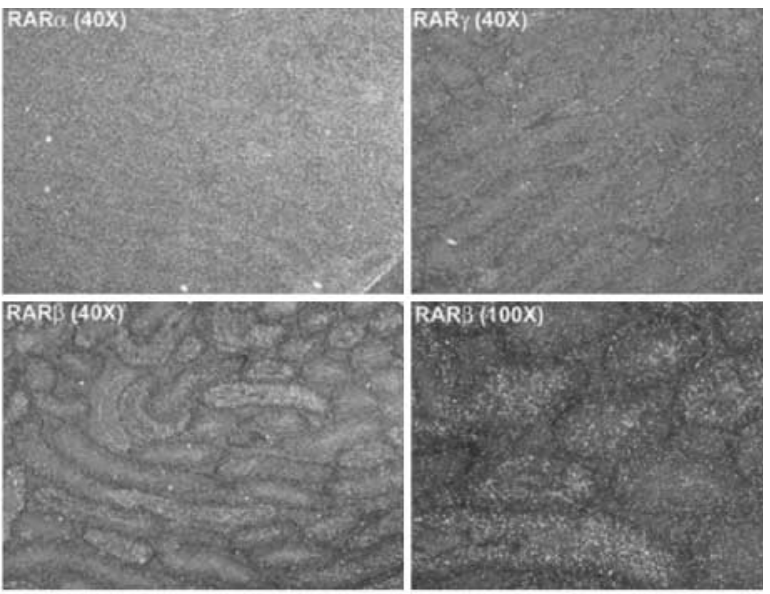

C Age of male mice (weeks)

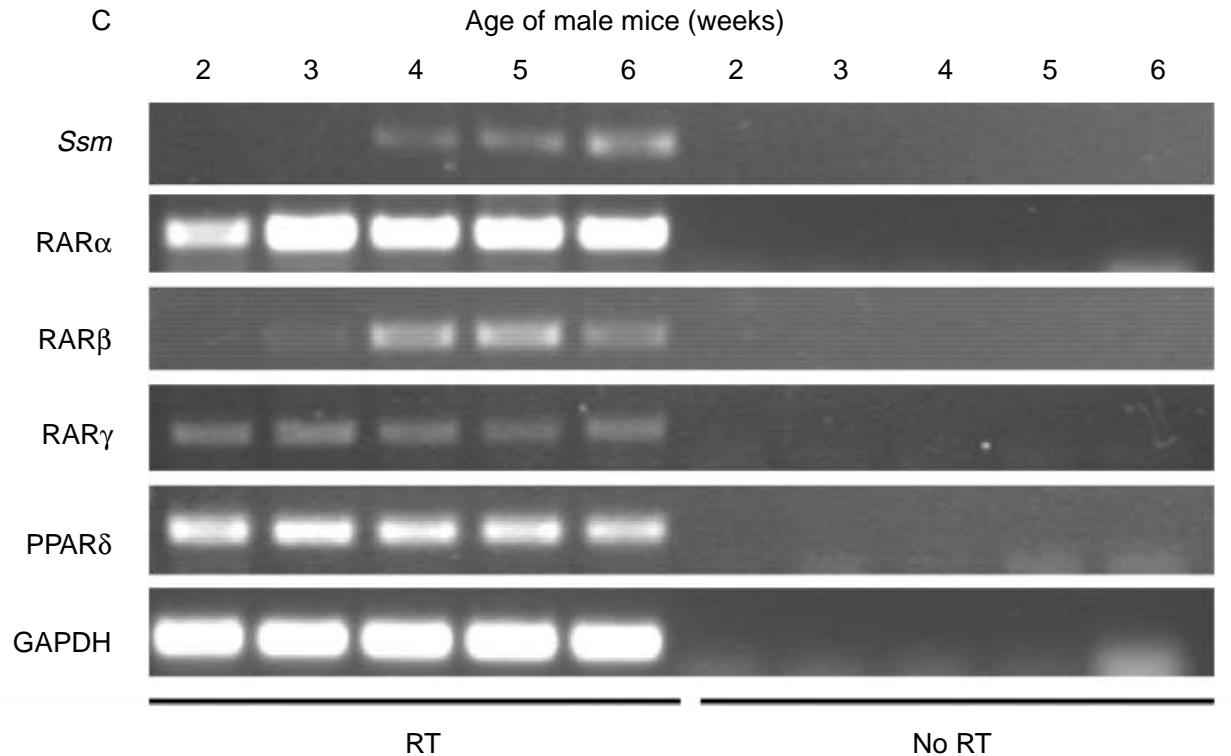

Figure 6 In situ hybridization of $S s m, R A R \alpha, R A R \beta$, and RAR $\gamma$. (A) In situ hybridization of the Ssm in the adult mouse testis. Dark-field photographs of representative sections are shown at the indicated magnification. Expression of $R b m$ is shown for comparison. (B) In situ hybridization of $\operatorname{RAR} \alpha, \beta$, and $\gamma$ in the adult mouse testis. Dark-field photographs of representative sections are shown at the indicated magnification. (C) RT-PCR analysis of RAR $\alpha, \operatorname{RAR} \beta, \operatorname{RAR} \gamma, \operatorname{PPAR} \delta$, and $S s m$ in mouse testis at 2-6 weeks of age.

selection minimizes false positives (Glozak et al. 2003). Although the screening was originally intended to find $\operatorname{PPAR} \delta$ target gene, co-transformation of $\mathrm{RXR} \alpha$ provided circumstance that enabled formation of another DR1binding dimer, $\mathrm{RXR} \alpha$ homodimer, in the presence of 9cRA (Heery et al. 1994). Indeed, there is ample evidence that DR1 is universally used by different combinations of nuclear receptors involving RXR (Durand et al. 1992, Nakshatri \& Chambon 1994, Mangelsdorf \& Evans 1995, Ludwig et al. 2000, IJpenberg et al. 2004). For example, DR1 and DR2 found in the promoter of cellular retinol-binding protein II (CRABPII) are shown to be activated by both RXR/RXR homodimer and RAR/RXR heterodimer (Durand et al. 1992). Furthermore, certain PPAR/RXR target genes, under in vivo conditions, can be selectively activated by RXR/RXR homodimer (IJpenberg et al. 2004). Furthermore, as our gel shift assays show, RAR/RXR heterodimer also binds to well-conserved DR1s found on the promoter of Ssm gene. Thus, it is clear that presence of DR1 within a promoter presents an opportunity for 
A
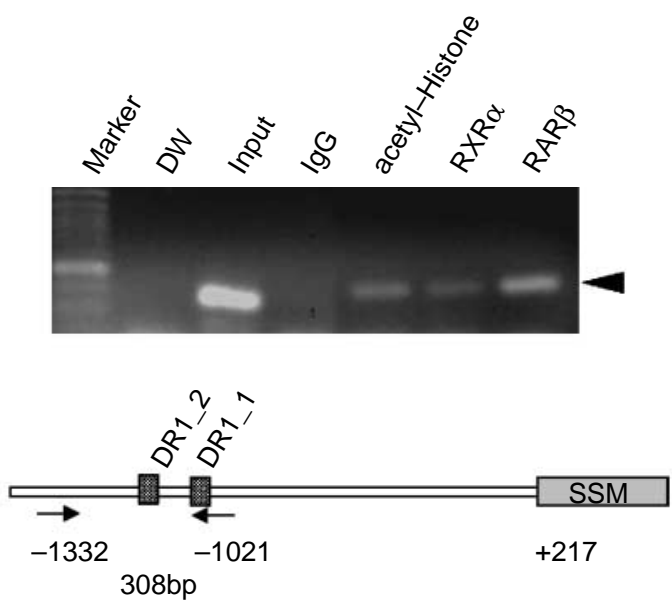

B

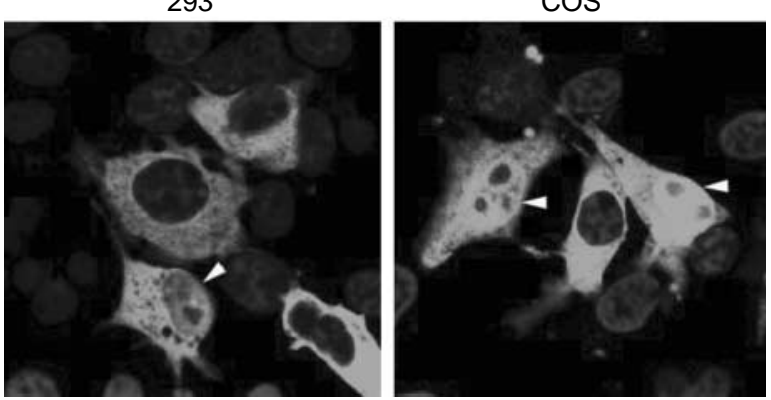

Figure 7 (A) In vivo chromatin immunoprecipitation of the DR1 region of the $S s m$. ChiP assays were performed using antibodies or antisera to acetyl-histone $\mathrm{H} 4, \mathrm{RXR} \alpha$, and RAR $\beta$ using cross-linked DNA-protein complexes from the mouse testis. Rabbit IgG served as negative control. Input DNA (positive control from PCR) was taken before the DNA-protein complexes were subjected to immunoprecipitation. DW, distilled water (negative control for PCR). (B) Subcellular localization of Ssm in HEK293 and COS cells. HEK293 and COS cells were transfected with CMV-Myc-Ssm fusion construct and subjected to confocal microscopy. Primary antibody was anti-Myc rabbit polyclonal antibody. A secondary antibody conjugated with Alexa Fluor 488 was used along with Topro-3 iodide, which stains nuclei in blue. The arrow heads point to Myc-positive staining.

promiscuous usage by nuclear receptor dimers depending on cellular context.

A primary determinant as to how a DR1 is utilized by nuclear receptors under in vivo condition would be the availability of ligands and the combination of available receptors. In this prospect, characterization of the gene under DR1 regulation should be accompanied by survey of available nuclear receptors under a specific cellular environment. As our expression analyses showed, $S s m$ is a unique marker gene of spermatocytes in the adult mouse testis. The finding that the Ssm promoter is most effectively regulated by tRA and 9cRA shows that $S s m$ is a RA-responsive gene involved in spermatogenesis. However, we failed to observe increases in Ssm expression in the testis RNA after exogenous RA or cPGI administration (data not shown). Since RA is required for spermatogenesis, there may be constant in situ production of RA in the testis, which makes in vivo induction experiment difficult (Vernet et al. 2006). Indeed, Ssm is highly expressed in specific populations of spermatogenic cells at all times after puberty (Fig. 6C). Thus, it is likely that RA administration would not further increase Ssm expression under the cellular environment of already enriched RA. Further investigations using RAR-deficient mouse models or vitamin A-deficient rodent model may provide more insights into the regulatory mechanism of $S s m$ expression.

In the vitamin A-deficient rodent model, defective proliferation of spermatogonia, abnormal progression in meiotic prophase, and delayed spermiation have been reported (Huang \& Marshall 1983, Griswold et al. 1989). Thus, multiple actions of RA using various combinations of RA receptors are expected. Recent investigation by others showed that while $\operatorname{RAR} \alpha, \operatorname{RAR} \gamma$, and $\operatorname{RXR} \beta$ are expressed in all tubules regardless of developmental stage of male germ cells, $\operatorname{RAR} \beta, \operatorname{RXR} \alpha$, and $\operatorname{RXR} \gamma$ are expressed mainly during later stages of spermatogenesis (Vernet et al. 2006). Our observations that $\operatorname{RAR} \beta$ localization resembles Ssm expression and that RAR $\beta$ shows binding to DR1s of the $S s m$ promoter under in vitro and in vivo conditions suggest that RAR $\beta$ may directly regulate $S s m$ during spermatogenesis.

In an independent library screening, Das and colleagues, also identified $S s m$ as a RA-target gene (Das et al. 2007). They found that $S s m$ is downregulated in the testes of $\operatorname{RAR} \alpha-$ deficient mice and vitamin D-deficient mice, which strongly suggest in vivo regulation Ssm by RA.

Ssm-positive cells in the mouse testis are morphologically most consistent with the secondary spermatocytes and early spermatids (Vernet et al. 2006). Judging from the cell typespecific expression pattern of Ssm in these cell types, this gene may be involved in later stages of spermatogenesis. The main cellular characteristics of these populations of cells are that they undergo second round of meiosis producing haploid germ cells and that they undergo transformation into spermatids via a process known as spermiogenesis. Thus, it is possible that Ssm may play a role during meiotic and morphological maturation processes of male germ cells. Further investigation using anti-Ssm antibody will clarify celltype specificity of $S s m$ expression and its potential functions.

So far, several marker genes demarcating developing and differentiating germ cells have been discovered. Rex-1 is a retinoic acid-regulated transcription factor expressed in both primary and secondary spermatocytes (Rogers et al. 1991). Soggy is also shown to be exclusively expressed in spermatocytes undergoing meiosis (Kaneko \& DePamphilis 2000). PTEN2 is a testis-specific phospholipid phosphatase and is cloned as a novel marker gene of secondary spermatocytes and early spermatids (Wu et al. 2001). Rbm is also a testis-specific gene with implications in early spermatogenesis. $\mathrm{Rbm}$ is expressed in early spermatocytes populations (Lee et al. 2004). It is still uncertain what physiological roles these stage-specific marker genes play 
during spermatogenesis. As a potential RAR $\beta$-target gene during later stages of spermatogenesis, Ssm may be associated with growth arrest and the differentiation pathway of the spermatocytes after completion of meiosis. RAR $\beta$ is known to mediate RA-induced cell growth arrest and increases in cell cycle regulatory molecules in F9 embryonic carcinoma cells (Faria et al. 1999, Li et al. 2004). Thus, Ssm may play a role as a potential effector of RA-induced cell growth arrest and differentiation during the specific process of male germ cell maturation.

Collectively, our results demonstrate a rare example of gene activation by RAR/RXR heterodimer via DR 1 element in a specific tissue. Detailed functional characterization of Ssm will reveal further insights into how RA regulates spermatogenesis.

\section{Acknowledgements}

The sequence data of the mouse $S s m$ has been deposited to the Genbank database under accession number DQ284430. This work was supported by the faculty research fund of Konkuk University in 2006. We appreciate the technical help of Ms J Hong and S Park for their help with in situ hybridization and chromatin immunoprecipitation respectively. The authors declare that there is no conflict of interest that would prejudice the impartiality of this scientific work.

\section{References}

Ausbel FM, Brent R, Kingston RE, Moore DD, Seidman JG, Smith JA \& Struhl K 1997 Current Protocols in Molecular Biology., New York: Wiley and Sons.

Chambon P 1996 A decade of molecular biology of retinoic acid receptors. FASEB Journal 10 940-954.

Cooke HJ \& Saunders PT 2002 Mouse models of male infertility. Nature Reviews. Genetics 3 790-801.

Cupp AS, Dufour JM, Kim G, Skinner MK \& Kim KH 1999 Action of retinoids on embryonic and early postnatal testis development. Endocrinology $1402343-2352$.

Das SK, Wang XN, Paria BC, Damm D, Abraham JA, Klagsbrun M, Andrews GK \& Dey SK 1994 Heparin-binding EGF-like growth factor gene is induced in the mouse uterus temporally by the blastocyst solely at the site of its apposition: a possible ligand for interaction with blastocyst EGF-receptor in implantation. Development 120 1071-1083.

Das P, Doyle TJ, Lin D, Kochar J, Kim KH \& Rogers MB 2007 Retinoic acid regulation of eye and testis-specific transcripts within a complex locus. Mechanisms of Development In press.

De Lucia F, Mennella MR, Quesada P \& Farina B 1996 Poly(ADPribosy1)ation system in transcriptionally active rat testis chromatin fractions.

Journal of Cellular Biochemistry 63 334-341.

Desvergne B \& Wahli W 1999 Peroxisome proliferator-activated receptors: nuclear control of metabolism. Endocrine Reviews 20 649-688.

Durand B, Saunders M, Leroy P, Leid M \& Chambon P 1992 All-trans and 9-cis retinoic acid induction of CRABPII transcription is mediated by RAR-RXR heterodimers bound to DR1 and DR2 repeated motifs. Cell $7173-85$

Eddy EM 1998 Regulation of gene expression during spermatogenesis. Seminars in Cell and Developmental Biology 9 451-457.

Eddy EM \& O'Brien DA 1998 Gene expression during mammalian meiosis. Current Topics in Developmental Biology 37 141-200.
Faria TN, Mendelsohn C, Chambon P \& Gudas LJ 1999 The targeted disruption of both alleles of RARbeta(2) in F9 cells results in the loss of retinoic acid-associated growth arrest. Journal of Biological Chemistry 274 26783-26788.

Glozak MA, Li Y, Reuille R, Kim KH, Vo MN \& Rogers MB 2003 Trapping and characterization of novel retinoid response elements. Molecular Endocrinology 17 27-41.

Griswold MD, Bishop PD, Kim KH, Ping R, Siiteri JE \& Morales C 1989 Function of vitamin A in normal and synchronized seminiferous tubules. Annals of the New York Academy of Sciences 564 154-172.

Hall BL, Smit-McBride Z \& Privalsky ML 1993 Reconstitution of retinoid X receptor function and combinatorial regulation of other nuclear hormone receptors in the yeast Saccharomyces cerevisiae. PNAS 90 6929-6933.

Heery DM, Pierrat B, Gronemeyer H, Chambon P \& Losson R 1994 Homoand heterodimers of the retinoid $\mathrm{X}$ receptor (RXR) activated transcription in yeast. Nucleic Acids Research 22 726-731.

Hofmann WA, Stojiljkovic L, Fuchsova B, Vargas GM, Mavrommatis E, Philimonenko V, Kysela K, Goodrich JA, Lessard JL, Hope TJ et al. 2004 Actin is part of pre-initiation complexes and is necessary for transcription by RNA polymerase II. Nature Cell Biology 6 1094-1101.

Huang HF \& Marshall GR 1983 Failure of spermatid release under various vitamin A states - an indication of delayed spermiation. Biology of Reproduction 28 1163-1172.

IJpenberg A, Tan NS, Gelman L, Kersten S, Seydoux J, Xu J, Metzger D, Canaple L, Chambon P, Wahli W et al. 2004 In vivo activation of PPAR target genes by RXR homodimers. EMBO Journal 23 2083-2091.

Kaneko KJ \& DePamphilis ML 2000 Soggy, a spermatocyte-specific gene, lies $3.8 \mathrm{~kb}$ upstream of and antipodal to TEAD-2, a transcription factor expressed at the beginning of mouse development. Nucleic Acids Research $\mathbf{2 8}$ 3982-3990.

Kastner P, Mark M, Leid M, Gansmuller A, Chin W, Grondona JM, Decimo D, Krezel W, Dierich A \& Chambon P 1996 Abnormal spermatogenesis in RXR beta mutant mice. Genes and Development 10 80-92.

Lee J, Hong J, Kim E, Kim K, Kim SW, Krishnamurthy H, Chung SS, Wolgemuth DJ \& Rhee K 2004 Developmental stage-specific expression of Rbm suggests its involvement in early phases of spermatogenesis. Molecular Human Reproduction 10 259-264.

Li R, Faria TN, Boehm M, Nabel EG \& Gudas LJ 2004 Retinoic acid causes cell growth arrest and an increase in p27 in F9 wild type but not in F9 retinoic acid receptor beta2 knockout cells. Experimental Cell Research 294 290-300.

Lim H, Paria BC, Das SK, Dinchuk JE, Langenbach R, Trzaskos JM \& Dey SK 1997 Multiple female reproductive failures in cyclooxygenase 2-deficient mice. Cell 91 197-208.

Lim H, Gupta RA, Ma WG, Paria BC, Moller DE, Morrow JD, DuBois RN, Trzaskos JM \& Dey SK 1999 Cyclo-oxygenase-2-derived prostacyclin mediates embryo implantation in the mouse via PPARdelta. Genes and Development 13 1561-1574.

Ludwig MG, Basset P \& Anglard P 2000 Multiple regulatory elements in the murine stromelysin-3 promoter. Evidence for direct control by CCAAT/enhancer-binding protein beta and thyroid and retinoid receptors. Journal of Biological Chemistry 275 39981-39990.

Lufkin T, Lohnes D, Mark M, Dierich A, Gorry P, Gaub MP, LeMeur M \& Chambon P 1993 High postnatal lethality and testis degeneration in retinoic acid receptor alpha mutant mice. PNAS 90 7225-7229.

Mader S, Leroy P, Chen JY \& Chambon P 1993 Multiple parameters control the selectivity of nuclear receptors for their response elements. Selectivity and promiscuity in response element recognition by retinoic acid receptors and retinoid X receptors. Journal of Biological Chemistry 268 591-600.

Mangelsdorf DJ \& Evans RM 1995 The RXR heterodimers and orphan receptors. Cell 83 841-850.

Mangelsdorf DJ, Umesono K, Kliewer SA, Borgmeyer U, Ong ES \& Evans RM 1991 A direct repeat in the cellular retinol-binding protein type II gene confers differential regulation by RXR and RAR. Cell 66 555-561.

Mangelsdorf DJ, Borgmeyer U, Heyman RA, Zhou JY, Ong ES, Oro AE, Kakizuka A \& Evans RM 1992 Characterization of three RXR genes that mediate the action of 9-cis retinoic acid. Genes and Development 6 329-344. 
Marcus SL, Miyata KS, Rachubinski RA \& Capone JP 1995 Transactivation by $\mathrm{PPAR} / \mathrm{RXR}$ heterodimers in yeast is potentiated by exogenous fatty acid via a pathway requiring intact peroxisomes. Gene Expression 4 227-239.

Morrison TB, Weis JJ \& Wittwer CT 1998 Quantification of low-copy transcripts by continuous SYBR Green I monitoring during amplification. Bio Techniques 24 954-958 (960, 962).

Mumberg D, Muller R \& Funk M 1995 Yeast vectors for the controlled expression of heterologous proteins in different genetic backgrounds. Gene 156 119-122.

Nakshatri H \& Chambon P 1994 The directly repeated RG(G/T)TCA motifs of the rat and mouse cellular retinol-binding protein II genes are promiscuous binding sites for RAR, RXR, HNF-4, and ARP-1 homoand heterodimers. Journal of Biological Chemistry 269 890-902.

Okazaki Y, Furuno M, Kasukawa T, Adachi J, Bono H, Kondo S, Nikaido I, Osato N, Saito R, Suzuki H et al. 2002 Analysis of the mouse transcriptome based on functional annotation of 60770 full-length cDNAs. Nature 420 $563-573$.

Pattenden SG, Klose R, Karaskov E \& Bremner R 2002 Interferon-gammainduced chromatin remodeling at the CIITA locus is BRG1 dependent. EMBO Journal 21 1978-1986.
Rogers MB, Hosler BA \& Gudas LJ 1991 Specific expression of a retinoic acid-regulated, zinc-finger gene, Rex-1, in preimplantation embryos, trophoblast and spermatocytes. Development 113 815-824.

Vernet N, Dennefeld C, Rochette-Egly C, Oulad-Abdelghani M, Chambon P, Ghyselinck NB \& Mark M 2006 Retinoic acid metabolism and signalling pathways in the adult and developing mouse testis. Endocrinology 147 96-110.

Wittwer CT, Herrmann MG, Moss AA \& Rasmussen RP 1997 Continuous fluorescence monitoring of rapid cycle DNA amplification. BioTechniques 22 130-138.

Wu Y, Dowbenko D, Pisabarro MT, llard-Telm L, Koeppen H \& Lasky LA 2001 PTEN 2, a Golgi-associated testis-specific homologue of the PTEN tumor suppressor lipid phosphatase. Journal of Biological Chemistry 276 $21745-21753$

Received in final form 30 November 2006

Accepted 6 December 2006

Made available online as an Accepted Preprint 27 December 2006 